\title{
Leadership Style of Multinational Corporations: A brief review
}

\author{
Al Sukri \\ alsukri_jn@comm.uir.ac.id \\ Tessa Shasrini \\ tessashasrini@comm.uir.ac.id \\ Fakultas Ilmu Komunikasi, Universitas Islam Riau
}

\begin{abstract}
While leadership is learned, the skills and knowledge processed by the leader can be influenced by his or hers attributes or traits such as beliefs, values, ethics and character, Knowledge and skills contribute directly to the process of leadership, while the other attributes give the leader certain characteristics that make him or her unique. The purpose of this study is to identify the Keys for Success in the Leadership of Multinational Corporations. Leadership is important for the design and development of organizational strategy and structure. Leadership styles differ and each leader selects a style best suited to his personality. The specific objective for this study is to determine the effectiveness of leadership traits that contributes to the success of Multinational corporations. This article reflect on case studies and example .
\end{abstract}

Keywords: leadership ; leadership style ; MNC ; Traits ; Organization.

\section{INTRODUCTION}

Today's global leaders need to adopt a challenging set of competencies to be effective in present-day global organizations for motivating and leading their multinational teams (Northouse, 2013). A key question is what makes a successful global leader the discussion is about how leadership is, or might be defined. There are hundreds of definitions of leadership and this is not an attempt to come to a consensus on a definition. The hope is to get readers to reflect on what they believe about leadership. It is also an attempt to give blog participants a general sense of how certain "experts" are describing leadership, in the hope that you may come to your own definition, which can then be used to guide your work. As the globalization trend continues, multinational companies (MNCs) recognize that leaders must learn to be effective in cross-cultural environments. By all measures, effective leadership is difficult in a "domestic" setting and adding expatriate duties makes leadership even more challenging. Leadership training and development is commonly used by companies for preparing "high potentials" to assume new roles at higher levels in the organization. Evidence of this trend toward combining leadership development with 
cross-cultural training is evident in the U.S. Army (Proctor, 2009), educational administration (Rhodes \& Brundrett, 2009), and of course academic study of leadership (van Emmerik, Euwema, \& Wendt, 2008). Some view leadership as a series of specific traits or characteristics. Others see it as comprised of certain skills and knowledge. And some, me included, think of leadership as a process. This view of leadership, as a process, places an emphasis on social interaction and relationship. This is the idea that leadership is a type of relationship, one that typically includes influencing others in a certain direction. This leads to my current working definition of leadership: Leadership is a relationship that involves the mobilizing, influencing, and guiding of others toward desired goals. This definition does not assume that the goals are shared or even explicit. The word desire simply means that someone in the relationship, perhaps just the person in a leadership role, wants a particular outcome. This definition of leadership transcends all the zones of the Action Wheel yet simultaneously applies fully in each one.

In any organization, leaders who have the power to incite and influence knowledge creation activities are at a natural advantage in their ability to play a central role in the process of knowledge creation and thus build competitive power for organizations. While scholars have emphasized a strong link between leadership styles and knowledge creation, the role of leadership in knowledge-creation activities has attracted scant attention (Mitchell \& Boyle, 2009; Tse \& Mitchell, 2010).

\section{LEADERSHIP}

The leadership and leader behavior plays an important role while achieving organizational goals. A leader should be directive, persuasive, consulting and delegating. Leadership is wise, adept choices by persons who singularly and collectively respond to and/or anticipate stirrings, embrace the challenge and courageously and faithfully serve the welcoming promise of authenticity Bob Terry (2008) And here is a brief explanation of each traits that a leader must have to successfully manage an organization

- Wise: Choices are wise when they integrate our reflections on experience, theory and frameworks, the testing of ideas, feedback from friends and critics, and constant learning and when they clarify and affirm our ethical and spiritual core.

- Adept: Choices are adept when they reflect astuteness and flexibility. We make adept choices when we are centered and living at the intersection of humility and engagement; avoiding both arrogance and adaptiveness. 
- Choices: We make a true choice when we own the responsibility of decision making, with no blaming of the past, the system, or others; seeing multiple options, not just dichotomous either/or thinking.

- Persons: singularly and collectively. We understand that individuals make a difference yet rarely does leadership center on just one person. Groups also make wise, adept choices.

- Respond to: and/or anticipate stirrings. We listen to the voices inside and outside that tell us they are aware of inauthenticity, voices that tell us we need to shift attention and appropriate action to be authentic again. The stirrings may be loud; they may be very quiet. Leaders who wish to have anticipatory wisdom learn to hear the quiet stirrings earlier than others do.

- Courageously: We take risks for a worthy, virtuous cause or circumstance with no guaranteed outcome.

- Embrace the challenge: We face the uncertainties of life, confront and resist evil, live in the midst of real chaos, and admit and own the despair and fears that are palpable in everyday life.

- Faithfully serve: We confirm through the way we live the abiding confidence that hope is grounded both outside and inside our personal or communal life. The challenges are real and ultimately addressable.

- Welcoming promise of authenticity: That which is true and real inside and outside us is worthy and deserving of commitment and service. We experience the really real every day even though we do not experience it fully. The welcoming promise of authenticity is confirmed only as we trust in and live out the promise every day. It is welcoming because it stirs us, invites us, scares us, and ultimately enhances us.

A number of researchers have been suggested that the leader behavior and leadership should be effectual and efficient. The previous literature posited two important concepts, consideration and initiating structure, to characterize the above qualities of effectual and efficient leader's behavior (Fleishman, Harris \& Burtt, 1955, Stogdill \& Coons, 1957), and Harris (1969) defines ' Consideration includes behavior indicating mutual trust, respect, and a certain warmth and rapport between the supervisor and his group and Initiating Structure includes behavior in which the supervisor organizes and defines group activities and his relation to the group. Yukl (1994) defines leadership as a social influence process he said, "Leadership is a group phenomenon, and there are no leaders without followers". According to him, leadership is to describe an organization's objectives and motivate the people to achieve these organizational objectives. The leaders who motivate and encourage their workers and subordinates will get more innovative and novel ideas that will help to gain more profit than those leaders 
who have an autocratic leadership style (Rotemberg \& Saloner 1993). Leaders carry out this process by applying their leadership knowledge and skills. This is called Process Leadership (Jago, 1982). However, we know that we have traits that can influence our actions. This is called Trait Leadership (Jago, 1982), in that it was once common to believe that leaders were born rather than made. These two leadership types are shown in the chart below (Northouse, 2007:5).

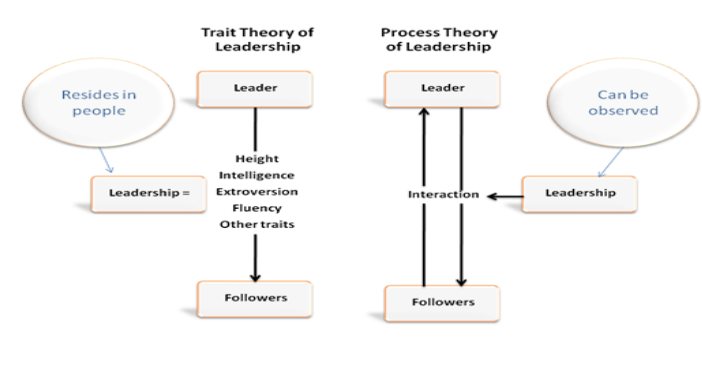

Leadership Style (Northouse, 2007)

According to Kirkpatrick and Locke (1991) attribute successful leadership to drive (a trait encompassing achievement, motivation, ambition, tenacity, and initiative), integrity, self-confidence, cognitive ability, and knowledge of the business. This research tends to refute, in part, the negativity associated with what has been described as the "trait school of leadership." Hakan V. Erkutlu , Jamel Chafra (2006) suggests in their studies that the leaders who use their powers and giving instructions to the workers without paying any attention on their ideas, it may cause negative effects in the organization. McKenna (2002) described that interactive leadership style provides help to organization to understand the needs of their workers, enhance their development, and in result achieve organizational goals and objectives. Darling and Walker, (2001) defines “A person's interactive leadership style reflects a pervasive and enduring set of interpersonal behavior". "Supportive leadership is the most frequent style of leadership in small organization. The supportive and participative leadership styles influence effectiveness in small organizations" by Pedrajarejas, Rodriguez ponce, 2006). According to Hakan V. Erkutlu, Jamel Chafra (2006), leadership is the core activity of management. The leaders in the organization use their personal power or authority would affect the subordinates attitudes and behavior. Further more he suggested that if we want to develop our organization on strong footing we must need to empower the leadership in the organization. The leaders who recognize the needs of their subordinates and given then respect, they will find respect in their subordinates. researchers as Karasek (1979), Ganster and 
Schaubroeck (1991), Kahn and Byosiere (1992), Elangovan and Xie (2000), Cohen and Wills (1985), Busch (1980), Podsakoff and Schriesheim (1985), Sheridan and Vredenburgh (1978) suggest that there is a positive relationship between leaders power and the job stress and negative relations between personal powers and job stress. Clarence J. Cunningham (1996) used two concepts of leader's behavior, initiation structure and consideration in his studies. He suggested, "Initiation structure is the combination of establishing communication channels, recognize new methodologies and procedures to achieve an organization goal whether consideration is the relation between a leader and the group members. Where an organization is harsh in its approach to failure, then the experience may lead to skills in defensiveness not learning from failure. The conceptual distinction between leader development and leadership development is a useful one, in fact Day argues that both types of development are important, and this is confirmed by other writers too (Latham and Sejits (1998). Alimo-Metcalfe and Lawler (2001), suggest that leadership development works best where attention is paid to organizational strategy and context, to make sure that leadership development is appropriately designed and implemented. Day (2001) explained as in below table: Human capital and social capital approaches to leadership development target (source: Day,2001)

Table 1: Human capital and social capital approaches to leadership development (Source : Day, 2001)

\begin{tabular}{|l|l|l|}
\hline $\begin{array}{l}\text { Comparison } \\
\text { dimension }\end{array}$ & Leader & Leadership \\
\hline Capital type & Human capital & Social capital \\
\hline Leadership model & $\begin{array}{l}\text { Individual } \\
\text { Personal power } \\
\text { Knowledge } \\
\text { Trustworthiness }\end{array}$ & $\begin{array}{l}\text { Relational } \\
\text { Commitments } \\
\text { Mutual respect } \\
\text { Trust }\end{array}$ \\
\hline Competence base & Intrapersonal & Interpersonal \\
\hline Skills & Self-awareness & Social awareness \\
& Emotional awareness & Empathy \\
& Self-confidence & Service orientation \\
& Accurate self-image & Political awareness \\
& Self-regulation & Social skills \\
& Self-control & Building bonds \\
& Trustworthiness & Team orientation \\
& Personal responsibility & Change catalyst \\
& Adaptability & Conflict management \\
& Self-motivation & \\
& Initiative & \\
\hline
\end{tabular}




\begin{tabular}{|l|l|l|}
\hline & $\begin{array}{l}\text { Commitment } \\
\text { Optimism }\end{array}$ & \\
\hline
\end{tabular}

From the discussion above we could see that leadership can be studied from many aspects. We would further enforce the meaning of leadership in the Multinational Organization( MNC). We are going to further discuss how do leaders of MNCs manage their organization to success and what traits are outstanding.

\section{Leadership Skill}

The qualities of a good leader are the same be it a domestic enterprise or a multinational corporation (MNC). A prominent person has defined leadership qualities as 'Leaders do not wait for opportunities. They decide their aims and limitation themselves. They search opportunities in challenges'. And the companies are of the opinion that real leadership is to get the results through team work. An effective leader is one who takes responsibility for the future of the corporation by preparing the organization to change from an average company to a great corporation. Sir Winston Churchill said: "The price of greatness is responsibility" (Churchill Centre, 2007), clearly indicating that to be a great leader one must take responsible actions to achieve success. A leader should be able to take decisions without haste, and he should be able to get the cooperation of the team mates and the courage to take risk is also important. Good leadership is not saying anything about a book just by watching the cover page.

There are some universal leadership principles that have been identified as being very effective when employed specifically in a multinational environment. Interestingly enough, these are biblical principles that global businesses inadvertently use to achieve success. Based on Goleman's (2000) research, effective leadership in a multinational environment can be achieved by employing three primary leadership styles stated as:

- Vision, mobilizing people toward change; - Serving, by building emotional bonds; - Leading others to greatness, by developing people for future responsibility.

Leaders in a multinational environment must in addition recognize the "limitations of one's own cultural norms" (Fernandez and Underwood, 2006, p.10). Leaders will have their most positive influence if they have a "willingness to recognize the limitations of their own cultural norms and accept and adapt to the culture of the host country" (Fernandez et al. 2006). MNC leaders need to appreciate that we are more exposed to the media and the political system than domestic corporations are, and must, therefore, always act in a transparent manner. 


\section{Keys to successful leadership}

Leadership is a winning combination of personal traits and the ability to think and act as a leader, a person who directs the activities of others for the good of all. Anyone can be a leader, even if the only person they're leading is themselves. Many people believe that leadership is simply being the first, biggest or most powerful. Leadership in organizations has a different and more meaningful definition. These are few examples of different types of leaders there are. There are also different roles of leadership such as senior-level executives and middle managers. Motivated leaders who have charisma and high levels of emotional stability will be honest and have integrity in the manner in which they lead. An effective leader must be respected by the members of his or her group in order to perform effective.

Another aspect of leadership includes leadership traits such as being influential and inspirational. There also different contexts of leadership, e.g, leading oneself, leading other individuals, leading groups, leading organizations. Some traits that are often associated with being an effective leader include a measure of intelligence, high energy, self-confidence, dominance, and a need for achievement. An effective, charismatic leader must lead by example. That leader must be able to know what is going on, the job or task that is being accomplished, and be able to lead the group into performing the task at hand successfully. When discussing any triumphant or flourishing organization or institution, the main attribute which will always surface when examining the true fabric of what allows a particular organization or institution to excel, will always be leadership.

The global marketplace is changing rapidly and competition is fiercer than ever. Asian companies are beginning to eclipse U.S. and European rivals in a range of industries, according to Business Week. Toyota will soon surpass General Motors as the largest auto manufacturer and the market cap of several Indian service companies are now approaching the size of General Motors.

\section{CASE STUDIES}

Leaders in a multinational environment must in addition recognize the "limitations of one's own cultural norms" (Fernandez and Underwood, 2006, p.10). Company like Toyota, which outperforms every other automobile maker every year, and it's really not the engineers," says Keim, a professor of management at the W. P. Carey School of Business and associate dean of the W. P. Carey MBA. "They've been reverseengineering [those processes] for 20 years in Detroit, but they can't recreate the products. It's really about the 'Toyota way' -- and that's a much more complicated system than engineering. 'Understanding the 'Toyota way,' says Keim, means 
understanding the company's highly complex, and highly successful, corporate culture. It's a culture that has helped Toyota excel in technology, sales and marketing, and become the most respected automaker in the world. It's also a culture that did not develop by accident: The Company's leaders made it happen. The leaders of an organization are the people who are responsible for formulating and implementing the strategy -- they're the ones deciding what they're going to do and then actually figuring out how they're going to do it. The leader is responsible for creating the vision and setting the direction for the future prosperity of the organization. Absence of a leader's vision is best described by Lewis Carroll. The corporate inspiration comes with "the alignment of people consistent with the leader's vision, setting the direction for change" (Kotter, 1990).

The leaders in Toyota Motors have a skill set that allows them to analyse the opportunities and the threats that may exist, both currently and going forward, and then being able to analyse the resources and abilities that an organization possesses to deal with those opportunities and threats. It also involves figuring out which resources and abilities must be developed to deal with future opportunities and threats. The rapidly changing, highly competitive environment of the $21^{\text {st }}$ century marketplace demands that executives be highly flexible and, though they may not like it, extremely humble. These are what the leaders in Toyota Motors do. By doing so, executives can increase their knowledge base, build smarter strategy, and move forward with a plan to implement that strategy that actually works. If employees don't believe in a strategy, they're not likely to help make it work. The different style of leadership brings different effects to the companies. Executives who seek input from all levels of their organization can build a knowledge base that allows them to formulate smarter strategy. Smart leadership can also help produce strong, healthy business cultures that make those strategies easier to implement. While autocratic leaders can help their companies make money, open-minded leaders are likely to help their companies make more money. As stated by Goleman and Kotter "a leader may need to embody more than one trait or leadership style to be successful" (Goleman et al. 2000).

India as we know has many large MNCs that are very successful we going to give some examples on the leaders of MNC in India. For example,P.L. Tandon, Vasant Rajadhyaksha, T. Thomas and A.S. Ganguly, all former Chairmen of Hindustan Lever; Don Kendall, Roger Enrico, Wayne Calloway and Steve Reinemund, all Chairmen and CEOs of PepsiCo. Each of them had a distinctive style; the common thread I found was their warmth and concern for people, and total commitment to the highest values of integrity. These towering personalities had character and transparency. Leaders in MNCs have grown and reached the top by virtue of their merit. The leader that intends to create a great company must "get the right people on 
the bus and the wrong people off" and then decide the direction of the corporation (Collins, 2001).

We would like to share some prerequisites for being a successful leader in a MNC in India. An Indian manager has to reflect the personality of the MNC he works for, never compromising on the values the company stands for. For an MNC to be successful in the long run, the leader must identify the MNC with national priorities, be seen to be a part of the Indian fabric, and put country gain before corporate gain. Leaders need to exhibit humility when dealing with people in a multinational environment by working to show sincerity in learning the culture Leaders in MNCs have to build a team of high calibre professionals, or lead one, if they have inherited such a team. They have to be consistent, fair and passionate. A passionate team such as in Pepsi or Hindustan Lever must take ownership for the vision of the company and its goals, and must put the corporation before self; such a team cannot but succeed. Hindustan Lever is an excellent example that portrays good leadership even though it is not the largest MNC. The successful leader will be the one who blends the universal principles of effective leadership with multicultural mind-set; this requires the ability to be open to the ideas and opinions of others (House et al., 2004)

\section{CONCLUSIONS}

Leadership is an essential ingredient for enhancement of the resource of an organization or a society to attain its desired goals. Dearth of good and effective leadership in all spheres of human endeavors' could be said to be the main clog in any societal development. Thus, the pathetic condition of our infrastructures, backward technology, high illiteracy rate and other societal decadences are attributable to poor and inept leadership, particularly in our political sphere. Therefore, in order to address this anomaly in the leadership question in our society in particular, and in developing or emerging society in general, it is hereby recommended that leadership should always be seen as a trust, which should be shouldered by only capable and credible people A leaders also should be made to be accountable for their stewardships both when in office and after wards, through legislative or any possible means.

Professionals and mass media should form vanguards that would serve as watch-dogs or whistle blowers to curtail the excesses of the leadership. Role model should be set in our spheres of human endeavor. Individuals should be sincere and selfless in their various fields of endeavor. There should be general societal re-orientation both from temporal and religious leaders and represent the posts decision exactly, in other cases, he or she must use independent judgment. You will need to solicit and analyze 
participants' views and attempt to represent those views within the guidelines of your post, your participating organization and exploring. Leadership must be people oriented. In other words people must be the centerpiece of leadership. Therefore, the leadership becomes relevant and effective if it is emphatic with the people aspirations and cultivates a sense of trust amongst the followers.

\section{ABOUT THE AUTHORS}

AL SUKRI is a lecturer at the school of communication science, Faculty of Communication Sciences, Universitas Islam Riau, Indonesia.

TESSA SHASRINI is a senior lecturer at the school of communication science, Faculty of Communication Sciences, Universitas Islam Riau, Indonesia.

\section{ACKNOWLEDGEMENT}

We especially indebted to Dr Zoharah Omar,who has supported actively to provide our article with the protected academic time to pursue those goals. Last but not the least we would like to thank our family and friend for their constant source of inspiration.

\section{REFERENCES}

Bass, Bernard (1990). From transactional to transformational leadership: learning to share the vision. Organizational Dynamics, 18, (3), Winter, 1990, 19-31.

Choen, W. (2008, August). Effective Leadership. Leadership Excellence, 25 (8).

Ciulla, J., 2006. 'Ethics and effectiveness: The fabric of leadership', Paper presented at the World Ethics Forum, Oxford University, 9-12 April 2006.

Collins, J. (2001). Good to Great, Why Some Companies Make the Leap and Others Don't. HarperCollins.

Counts, G. E Farmer, R. F \& Sheapard, I. S (1995) Leadership: too exclusive for definition? Journal of Leadership Studies, 2 (3), 30-41

Dooley, L., \& O'Sullivan, D. (2001). Structuring Innovation: A Conceptual Model and ImplementationFernandez, A. J. \& Underwood, L. (2006). CHINA CEO: Voices of Experience from 20 International Business Leaders.

Fielder, F. E., (1967) A Theory of Leadership Effectiveness, New York: McGraw Hill.

Goleman, D. (2000). Leadership That Gets Results. Harvard Business Review. Harvard: HarvardBusiness School Publishing Corporation, Publication Number R00204. 
Hofstede, G., 1980. 'Motivation, leadership and organizations: Do American theories apply abroad?', Organizational Dynamics 9: 42-63.

House, J.R., Hanges J.P., Mansour, J., Dorfman, J.P., \& Gupta, V. (2004). Culture, Leadership, and Organizations - The Increased Importance of Sensitivity to Cultural Differences. Sage.

House, R.J (1971) "A Path-Goal Theory of Leader Effectiveness", Administrative Science Quarterly, 16, 321-339.

Ivancevich, J., Konopaske, R., Matteson, M. (2007). Organizational Behavior and Management. New York: McGraw-Hill Irwin.

Jago, A. G. (1982). Leadership: Perspectives in theory and research. Management Science, 28(3),315-336.

Kotter, J. P. (1990). What Leaders Really Do. Harvard Business Review, Harvard Business School Publishing Corporation, Publication Number R0111F.

Kouzes, James M. \& Posner, Barry Z. (1987). The Leadership Challenge. San Francisco: Josse

Lamb, L. F., McKee, K. B. (2004). Applied Public Relations: Cases in Stakeholder Management. Mahwah, New Jersey: Lawrence Erlbaum Associates. Routledge.

Lorsch, Jay W. (Spring 1974). "Review of Leadership and Decision Making". Sloan Management Review.

McGregor, D. (1960) The Human Side of Enterprise, New York: McGraw Hill.

Mischel, W. 1968. Personality and Assessment . New York: Wiley.

Mitchell, R. J., \& Boyle, B. (2009). A theoretical model of transformational leadership's role in diverse teams. Leadership \& Organization Development Journal, 30(5), 455-474

Newstrom, J. \& Davis, K. (1993). Organization Behavior: Human Behavior at Work. New York: McGraw-Hill.

Northouse, G. (2007). Leadership theory and practice. (3rd ed.) Thousand Oak, London, New Delhe, Sage Publications, Inc.

Northouse, P. G. (2013). Leadership - Theory and Practice (6th ed), Thousand Oaks, California: SAGE Publications, Inc

Rost, J. C (1993) Leadership for the twenty-first century. Westport,CN Praeger Publishers

Rowe, W. G. (2007). Cases in Leadership. Thousand Oaks, CA: Sage Publications

Sergiovanni, T.J (1995). The Principalship A reflective practice perspective (3rd.ed) Needham Heights,MA:Allyn and Bacon

Tonnenbaum, R., Wesschler, I.R. and Massarik, F. (1961) Leadership and Organization, New York: McGraw Hill

Vroom, V.H., and Yetton, P.W. (1973) Leadership and Decision-Making, Pittsburgh: University of Pittsburgh press.

Weiss, W. (2000, August). Effective Leadership: What are the Requisites? Supervision, 61(8).

Youndt, M.A., Snell, S.A., Dean, J.W. and Lepak, D.P. (1996). 'Human resource management: manufacturing strategy and firm performance'. Academy of Management Journal, 39(4), 836-866. 